\title{
Pentastome assemblages of the Nile crocodile, Crocodylus niloticus Laurenti (Reptilia: Crocodylidae), in the Kruger National Park, South Africa
}

\author{
Kerstin Junker $^{1}$, Frikkie Calitz ${ }^{2}$, Danny Govender ${ }^{3}$, Boris R. Krasnov ${ }^{4}$ and Joop Boomker ${ }^{5}$ \\ ${ }^{1}$ Agricultural Research Council-Onderstepoort Veterinary Institute, Parasites, Vectors and Vector-borne Diseases Programme, \\ Onderstepoort, South Africa; \\ ${ }^{2}$ Agricultural Research Council-Biometry, Pretoria, South Africa; \\ ${ }^{3}$ South African National Parks, Skukuza, South Africa; \\ ${ }^{4}$ Mitrani Department of Desert Ecology, Swiss Institute for Dryland Environmental and Energy Research, Jacob Blaustein Institutes \\ for Desert Research, Ben-Gurion University of the Negev, Sede-Boqer Campus, Midreshet Ben-Gurion, Israel; \\ ${ }^{5}$ University of Pretoria, Department of Veterinary Tropical Diseases, Onderstepoort, South Africa
}

\begin{abstract}
Thirty-two specimens of the Nile crocodile, Crocodylus niloticus Laurenti (Reptilia: Crocodylidae), from the Kruger National Park, South Africa, and its vicinity were examined for pentastomid parasites during 1995 to 1999 and 2010 to 2011. Pentastomid parasites occurred throughout the year and were widespread in the study area with an overall prevalence of $97 \%$ and an overall mean abundance of 23.4 (0-81). Pentastome assemblages comprised six species in three sebekid genera: Alofia nilotici Riley et Huchzermeyer, 1995, A. simpsoni Riley, 1994, Leiperia cincinnalis Sambon, 1922, Sebekia cesarisi Giglioli in Sambon, 1922, S. minor (Wedl, 1861) and S. okavangoensis Riley et Huchzermeyer, 1995. The possible influence of host age, gender and geographic location (river system) on pentastome prevalence, abundance and species richness was investigated. Generally, neither host age, gender nor locality did affect infracommunities, likely because all hosts examined were adult or subadult and displayed comparable foraging behaviour, resulting in similar exposure pathways to fish intermediate hosts. Additionally, the longevity of pentastomids would contribute to accumulative infections as hosts mature. Structuring of pentastome assemblages was observed in as far as S. minor was the dominant species based on overall prevalence and abundance, followed by the equally common species $S$. cesarisi and L. cincinnalis. With an overall prevalence ranging from $34 \%$ to $41 \%$ and relatively low abundances, A. nilotici, A. simpsoni and S. okavangoensis form the rarer component of pentastome communities.
\end{abstract}

Keywords: Alofia, Leiperia, Sebekia, Pentastomida, abundance, prevalence, species richness, crocodilians

Crocodiles are considered by many a fascinating part of the African vertebrate fauna. Recent morphological and genetic studies have shown this continent to be home to three crocodylid genera, Crocodylus Laurenti, Osteolaemus Cope and Mecistops Gray. Mecistops is represented by a single species, $M$. cataphractus (Cuvier), while the traditionally two subspecies of Osteolaemus are now recognised as separate species, O. tetraspis Cope and O. osborni (Schmidt), with likely a third taxonomic entity present in this genus (Brochu 2007, Eaton et al. 2009).

Crocodylus niloticus Laurenti is the only species inhabiting southern Africa, with its southernmost viable natural populations found in formally protected areas in South Africa, namely the Kruger National Park (KNP), Lake St Lucia, Pongolapoort Dam and Ndumo Game Reserve (Ross 1989, Patterson 1991, Calverley and Downs 2015). While listed on the IUCN Red List of Threatened Species as of least concern (Crocodile Specialist Group 1996a), some of the populations of Nile crocodiles in South Africa have undergone severe setbacks in recent years (Calverley and Downs 2015).

Populations of Mecistops and Osteolaemus are largely restricted to the tropical forest zone of west and central Africa, where their range overlaps with that of $C$. niloticus (see Ross 1989). Osteolaemus is currently listed as vulnerable (Crocodile Specialist Group 1996b), but recognition of the former subspecies as two valid species would decrease the population size of each of these considerably, and Mecistops has reached the status of a critically endangered species (Shirley 2014). While reports of pentastomid parasites having a detrimental effect on adult crocodiles under natural conditions are scarce, pentastomids can

Address for correspondence: K. Junker, Parasites, Vectors and Vector-borne Diseases Programme, Agricultural Research Council-Onderstepoort Veterinary Institute, Private Bag X05, Onderstepoort, 0110, South Africa. Phone: +27 12529 9215; Email: junkerk@arc.agric.za 


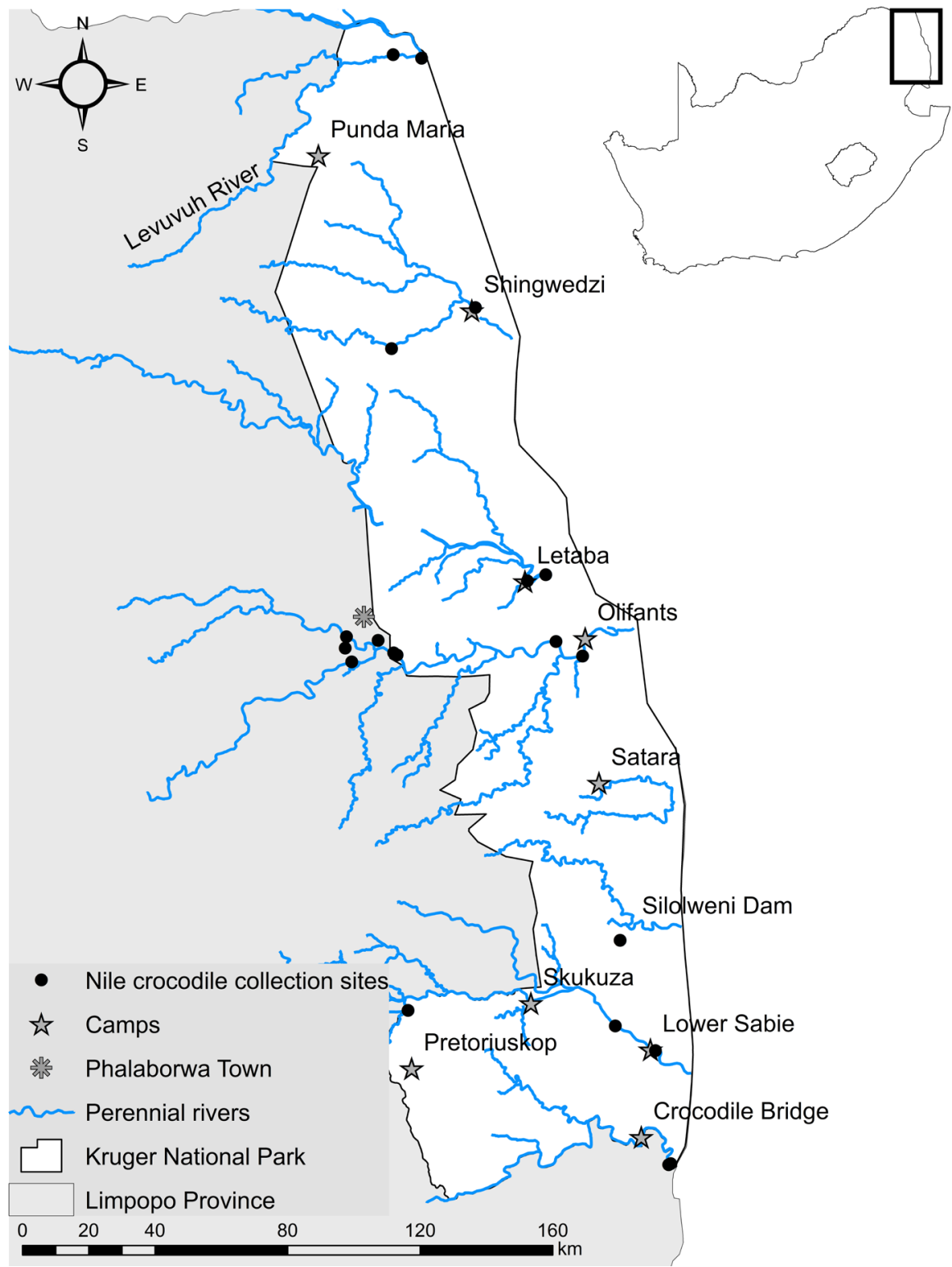

Fig. 1. Collection sites of Nile crocodiles in the Kruger National Park, South Africa and its vicinity. For reference of global positioning system points, see Table 1 .

cause substantial necrosis and haemorrhaging in the lungs and liver of infected hosts and have the potential of causing mortalities when associated with secondary bacterial infections (Shotts et al. 1972, Hazen et al. 1978, Junker et al. 1999). Given the possible impact of these parasites on their hosts and considering that pentastomids have been reported from all three crocodilian genera in Africa, it is regrettable that data on the pentastome assemblages of African crocodiles are scant, usually limited to prevalence and intensity records from a few hosts, with a main focus on taxonomic aspects (Riley 1994, Riley and Huchzermeyer 1995a,b, Riley et al. 1997, Junker et al. 1999, 2000).

In the present paper we provide the first comprehensive study of the pentastome assemblages of a comparatively large sample of 32 Nile crocodiles from the KNP, South Africa, using prevalence, mean abundance and species richness as parasitological descriptors.

\section{MATERIALS AND METHODS}

During the period from 1995 to 1999 and from 2010 to 2011, 16 Nile crocodiles each were collected from different localities in the KNP, South Africa (Fig. 1, Table 1). These crocodiles (18 males, 14 females) were examined as part of unrelated studies on their blood chemistry and disease ecology parameters, providing the rare opportunity to collect information on their pentastomid parasites. The six rivers from which crocodiles were sampled represent the two major river systems that drain the KNP, the Limpopo System to the north of the $24^{\circ} 15^{\prime}$ latitude and the Incomati System to the south of it (Pienaar 1968). From north to south, the Levuvhu (number of crocodiles $=2$ ), Shingwedzi $(\mathrm{n}=5)$, Letaba $(\mathrm{n}=2)$ and Olifants $(\mathrm{n}=10)$ Rivers contribute to the Limpopo System, whereas the Sabie $(n=4)$ and Crocodile $(n=2)$ Rivers form part of the Incomati System. Excepting the Shingwedzi, which is seasonal, but retains a number of permanent and semi-permanent pools along its length, these rivers 
Table 1. Collection data of 32 Nile crocodiles collected in the Kruger National Park and vicinity, South Africa.

\begin{tabular}{|c|c|c|c|c|c|c|c|}
\hline Locality & Date & Coordinates & Sex & $\mathrm{TL}(\mathrm{cm})$ & $\mathrm{SVL}(\mathrm{cm})$ & Weight $(\mathrm{kg})$ & Gonads \\
\hline Sabie River & $22 / 02 / 1995$ & $25^{\circ} 01^{\prime} \mathrm{S} ; 31^{\circ} 15^{\prime} \mathrm{E}$ & M & 320 & - & - & - \\
\hline Olifants River & $20 / 07 / 1997$ & $24^{\circ} 05^{\prime} \mathrm{S} ; 31^{\circ} 45^{\prime} \mathrm{E}$ & M & 350 & - & - & - \\
\hline Olifants River & $23 / 09 / 1997$ & $24^{\circ} 05^{\prime} \mathrm{S} ; 31^{\circ} 45^{\prime} \mathrm{E}$ & $\mathrm{F}^{*}$ & 210 & - & - & - \\
\hline Olifants River & 23/09/1997 & $24^{\circ} 05^{\prime} \mathrm{S} ; 31^{\circ} 45^{\prime} \mathrm{E}$ & $\mathrm{M}^{*}$ & 260 & - & - & - \\
\hline Olifants River & $24 / 09 / 1997$ & $24^{\circ} 05^{\prime} \mathrm{S} ; 31^{\circ} 45^{\prime} \mathrm{E}$ & M & 350 & - & - & - \\
\hline Olifants River & $25 / 09 / 1997$ & $24^{\circ} 05^{\prime} \mathrm{S} ; 31^{\circ} 45^{\prime} \mathrm{E}$ & $\mathrm{F}^{*}$ & 140 & - & - & - \\
\hline Olifants River ${ }^{\text {a }}$ & $25 / 09 / 1997$ & $24^{\circ} 05^{\prime} \mathrm{S} ; 31^{\circ} 45^{\prime} \mathrm{E}$ & M & 420 & - & - & - \\
\hline Sabie River ${ }^{a}$ & $26 / 09 / 1997$ & $24^{\circ} 09^{\prime} \mathrm{S} ; 31^{\circ} 05^{\prime} \mathrm{E}$ & $M^{*}$ & 240 & - & - & - \\
\hline Sabie River ${ }^{a}$ & 27/09/1997 & $24^{\circ} 09^{\prime} \mathrm{S} ; 31^{\circ} 05^{\prime} \mathrm{E}$ & M & 390 & - & - & - \\
\hline Shingwedzi River & $10 / 06 / 1998$ & $23^{\circ} 13^{\prime} \mathrm{S} ; 30^{\circ} 12^{\prime} \mathrm{E}$ & $\mathrm{F}$ & 280 & - & - & - \\
\hline Shingwedzi River & $10 / 06 / 1998$ & $23^{\circ} 13^{\prime} \mathrm{S} ; 30^{\circ} 12^{\prime} \mathrm{E}$ & $\mathrm{M}^{*}$ & 240 & - & - & - \\
\hline Shingwedzi River & $10 / 06 / 1998$ & $23^{\circ} 13^{\prime} \mathrm{S} ; 30^{\circ} 12^{\prime} \mathrm{E}$ & $\mathrm{F}$ & 320 & - & - & - \\
\hline Shingwedzi River & $10 / 06 / 1998$ & $23^{\circ} 13^{\prime} \mathrm{S} ; 30^{\circ} 12^{\prime} \mathrm{E}$ & $\mathrm{F}$ & 270 & - & - & - \\
\hline Olifants River & 16/03/1999 & $24^{\circ} 02^{\prime} \mathrm{S} ; 31^{\circ} 40^{\prime} \mathrm{E}$ & M & 380 & - & - & - \\
\hline PMC & 06/04/1999 & $24^{\circ} 55^{\prime} \mathrm{S} ; 31^{\circ} 10^{\prime} \mathrm{E}$ & M & 390 & - & - & - \\
\hline PMC & $15 / 06 / 1999$ & $24^{\circ} 55^{\prime} \mathrm{S} ; 31^{\circ} 10^{\prime} \mathrm{E}$ & $\mathrm{F}$ & 260 & - & - & - \\
\hline Crocodile River & $12 / 07 / 2010$ & $25^{\circ} 27^{\prime} \mathrm{S} ; 31^{\circ} 58^{\prime} \mathrm{E}$ & $\mathrm{F}$ & 260 & 141 & 70 & maturing $20 \mathrm{~mm}$ follicles \\
\hline Crocodile River & $12 / 07 / 2010$ & $25^{\circ} 25^{\prime} \mathrm{S} ; 31^{\circ} 58^{\prime} \mathrm{E}$ & $\mathrm{F}$ & 292 & 165 & 102 & maturing $20 \mathrm{~mm}$ follicles \\
\hline Olifants River & $13 / 07 / 2010$ & $24^{\circ} 02^{\prime} \mathrm{S} ; 31^{\circ} 13^{\prime} \mathrm{E}$ & M & 373 & 202 & 226 & mature, active testes \\
\hline Olifants River & $13 / 07 / 2010$ & $24^{\circ} 03^{\prime} \mathrm{S} ; 31^{\circ} 13^{\prime} \mathrm{E}$ & M & 323 & 181 & 111 & immature \\
\hline Shingwedzi River & $13 / 07 / 2010$ & $23^{\circ} 07^{\prime} \mathrm{S} ; 31^{\circ} 27^{\prime} \mathrm{E}$ & M & 313 & 170 & 118 & maturing, inactive testes \\
\hline Levuvuh River & $13 / 07 / 2010$ & $22^{\circ} 43^{\prime} \mathrm{S} ; 31^{\circ} 30^{\prime} \mathrm{E}$ & M & 323 & 176 & 127 & mature, active testes \\
\hline Levuvuh River & $13 / 07 / 2010$ & $22^{\circ} 25^{\prime} \mathrm{S} ; 31^{\circ} 13^{\prime} \mathrm{E}$ & M & 385 & 203 & 268 & mature, active testes \\
\hline Silolweni Dam & $15 / 07 / 2010$ & $24^{\circ} 49^{\prime} \mathrm{S} ; 31^{\circ} 50^{\prime} \mathrm{E}$ & $\mathrm{F}$ & $304^{\mathrm{b}}$ & 184 & 210 & mature, active ovaries \\
\hline Silolweni Dam & $15 / 07 / 2010$ & $24^{\circ} 49^{\prime} \mathrm{S} ; 31^{\circ} 50^{\prime} \mathrm{E}$ & $M^{*}$ & 282 & 147 & 85 & immature \\
\hline Letaba River & $15 / 07 / 2010$ & $23^{\circ} 50^{\prime} \mathrm{S} ; 31^{\circ} 38^{\prime} \mathrm{E}$ & $\mathrm{F}$ & 280 & 150 & 80 & mature $40 \mathrm{~mm}$ follicles \\
\hline Letaba River & $15 / 07 / 2010$ & $23^{\circ} 51^{\prime} \mathrm{S} ; 31^{\circ} 35^{\prime} \mathrm{E}$ & $\mathrm{F}$ & 280 & 150 & 83 & mature $40 \mathrm{~mm}$ follicles \\
\hline Sabie River & $15 / 07 / 2010$ & $25^{\circ} 07^{\prime} \mathrm{S} ; 31^{\circ} 55^{\prime} \mathrm{E}$ & M & $390^{c}$ & 232 & 338 & mature testes \\
\hline PMC & $07 / 02 / 2011$ & $24^{\circ} 02^{\prime} \mathrm{S} ; 31^{\circ} 05^{\prime} \mathrm{E}$ & $\mathrm{F}$ & 299 & - & 113 & two $10 \mathrm{~mm}$ degenerating follicles \\
\hline Olifants River & 08/02/2011 & $24^{\circ} 04^{\prime} \mathrm{S} ; 31^{\circ} 06^{\prime} \mathrm{E}$ & $\mathrm{F}$ & 330 & - & 160 & mature, inactive ovaries \\
\hline PMC & $08 / 02 / 2011$ & $24^{\circ} 00^{\prime} \mathrm{S} ; 31^{\circ} 06^{\prime} \mathrm{E}$ & $\mathrm{F}^{*}$ & 190 & - & - & immature \\
\hline PMC & $09 / 02 / 2011$ & $24^{\circ} 01^{\prime} \mathrm{S} ; 31^{\circ} 11^{\prime} \mathrm{E}$ & M & 346 & - & 170 & mature, inactive testes \\
\hline
\end{tabular}

${ }^{\text {a }}$ pentastomids collected from right lung only, counts doubled for comparison; ${ }^{b}$ part of the tail missing, estimated length: $340 \mathrm{~cm}$; ${ }^{\mathrm{c}}$ part of the tail missing, estimated length: $460 \mathrm{~cm}$; Fulton's k - body condition factor (see Zweig 2003); F - adult female; M - adult male; PMC-sedimentation dams at the Phalaborwa Mining Complex; SVL - snout-vent length; TL - total body length; * subadult.

are perennial (Pienaar 1968). In addition, an impounded internal stream (Silolweni Dam; $\mathrm{n}=2$ ) and several permanent sedimentation dams of the Phalaborwa Mining Complex (PMC; $\mathrm{n}=5$ ) just outside the KNP, with crocodiles therein having migrated from either the Olifants or Selati Rivers, were sampled. A single additional crocodile collected from the Letaba River in 1995 harboured an unusually large number $(n=239)$ of pentastomids in its heart, trachea, bronchi and lungs and was therefore excluded from this study. Its pentastome assemblage and associated pathological lesions were described by Junker et al. (1999).

The first group of crocodiles were shot and immediately processed in the field, whereas the second group was shot in the field and subsequently transported to the post mortem facilities at Skukuza, the Park's scientific headquarters. All crocodiles were examined within $12 \mathrm{~h}$ of death, as some had to be stored overnight. Night temperatures did not exceed $5^{\circ} \mathrm{C}$ and no significant post mortem migration of pentastomids was observed in the respiratory tracts or hearts of these animals. Total length (TL, from the tip of the snout to the tip of the tail), sex, overall body condition and, in the case of the second group, gonad development, weight and snout-vent length (SVL; $\mathrm{n}=12$; 141-232 cm) were determined. The overall mean TL was $303.2 \mathrm{~cm}(140-420 \mathrm{~cm})$, and the overall mean body weight was $151 \mathrm{~kg}(70-338 \mathrm{~kg})$.
Based on the information obtained from the 12 crocodiles for which information on TL, SVL and gonad development was available, crocodiles were classified as subadults or adults (Table 1). Crocodiles with maturing gonads were included in the group of adults for the purpose of this study. As such, the shortest female that had reached sexual maturity, as evidenced by maturing follicles of $20 \mathrm{~mm}$ diameter, had a TL of $260 \mathrm{~cm}$ $(\mathrm{SVL}=141 \mathrm{~cm})$. We therefore classified females with a TL of $<260 \mathrm{~cm}$ as subadult and those with a TL of $\geq 260 \mathrm{~cm}$ as adult females. A male of $323 \mathrm{~cm} \mathrm{TL}(\mathrm{SVL}=181 \mathrm{~cm})$ was found to be immature. However, another crocodile of the same TL and a shorter SVL of $176 \mathrm{~cm}$ possessed mature testes and a male of slightly smaller size $(\mathrm{TL}=313 ; \mathrm{SVL}=170)$ possessed maturing testes. We therefore decided to take the TL of the next smaller male with immature gonads as cut-off point for sexual maturity. Thus, males of $\leq 282 \mathrm{~cm}$ TL were classified as subadults, and males with a TL of $>282 \mathrm{~cm}$ as adults.

This classification conforms with the size ranges for mature crocodiles established by Kofron (1990) for Nile crocodiles in Zimbabwe, where females attained sexual maturity after having reached a length of $262-287 \mathrm{~cm}$, and males of $270-295 \mathrm{~cm}$. Calverley and Downs (2015) categorised Nile crocodiles in Ndumo Game Reserve, South Africa, as subadults $(150-250 \mathrm{~cm})$ and adults $(>250 \mathrm{~cm})$. When applying their classification to the pres- 
Table 2. Prevalence and mean abundance (MA) of pentastomid parasites collected from 32 Nile crocodiles in the Kruger National Park and vicinity, South Africa.

\begin{tabular}{|c|c|c|c|c|c|}
\hline Species $^{\mathrm{a}}$ & Infected hosts $(\mathrm{N})$ & Prevalence $(\%)$ & Total count & MA & MA range \\
\hline Leiperia cincinnalis Sambon, 1922 & 18 & 56 & 170 & 5.3 & $0-39$ \\
\hline Leiperia cincinnalis IL & 11 & 34 & 95 & 3.0 & $0-33$ \\
\hline Alofia nilotici Riley et Huchzermeyer, 1995 & 13 & 41 & 37 & 1.2 & $0-12$ \\
\hline Alofia simpsoni Riley, 1994 & 11 & 34 & 42 & 1.3 & $0-11$ \\
\hline Sebekia cesarisi Giglioli in Sambon, 1922 & 23 & 72 & 111 & 3.5 & $0-22$ \\
\hline Sebekia minor (Wedl, 1861) & 22 & 69 & 360 & 11.3 & $0-54$ \\
\hline Sebekia okavangoensis Riley et Huchzermeyer, 1995 & 11 & 34 & 29 & 0.9 & $0-9$ \\
\hline Sebekidae gen. sp. adults ${ }^{\mathrm{b}}$ & 10 & 31 & 17 & 0.5 & $0-6$ \\
\hline Sebekidae gen. sp. IL ${ }^{b}$ & 12 & 38 & 66 & 2.1 & $0-16$ \\
\hline Pentastomida total $^{c}$ & 31 & 97 & 749 & 23.4 & $0-81$ \\
\hline
\end{tabular}

${ }^{\mathrm{a}}$ adult stages unless otherwise stated; ${ }^{\mathrm{b}}$ excepting Leiperia cincinnalis; ${ }^{\mathrm{c}}$ based on adult specimens identified to species level; IL - infective larvae.

ent data set, two males currently classified as subadults would be considered adult. Since one of these males was clearly identified as immature based on gonad development, we have retained the age classes as set out earlier.

The nasopharynx, trachea, lungs, heart and aorta of each crocodile were examined for parasites as described by Junker et al. (2000). For one crocodile from the Olifants River and two crocodiles from the Sabie River, only the right lungs were available for parasite collection; counts were doubled for comparison. Pentastomes were fixed in hot $70 \%$ ethanol, stored in cold $70 \%$ ethanol and subsequently mounted and cleared in Hoyer's medium for identification under a compound microscope. Voucher material of larval and adult pentastomes was deposited in the National Collection of Animal Helminths, Agricultural Research Council-Onderstepoort Veterinary Institute, Onderstepoort, South Africa (accession numbers $S / 2015 / 15-20$ ). For the purpose of this study, we did not distinguish between the infective larvae of the genera Alofia Giglioli in Sambon, 1922 and Sebekia Sambon, 1922, but recorded them as sebekid infective larvae. They were easily differentiated from the infective larvae of Leiperia Sambon, 1922.

The terms prevalence, (mean-) abundance and species richness are used as per the definitions of Bush et al. (1997). The classification of pentastomid parasites follows Poore (2012).

\section{Statistical procedures}

For data analysis, crocodiles were assigned to different abiotic and biotic population subgroups: season (spring: SeptemberNovember, summer: December-February, autumn: March-May and winter: June-August); river system (Incomati System and Limpopo System); sex (male and female) and age (subadult and adult). Because of the low number of crocodiles obtained from them, the PMC and Silolweni Dam were not included in statistical analyses pertaining to differences between systems. Similarly, only descriptive statistics are presented with regards to crocodiles collected during the various seasons. Species richness and overall/total counts were determined based on adult pentastomids identified to species level.

We tested for the effect of crocodile sex, age and river system in which a crocodile was collected on the number of (a) adult pentastomids identified to species level, (b) infective larvae of Leiperia cincinnalis Sambon, 1922, (c) infective larvae of the Sebekidae, excluding those of $L$. cincinnalis, i.e. Alofia spp. plus Sebekia spp., and (d) number of pentastomid species (based on adult pentastomids only and excluding unidentified sebekids) harboured by an individual crocodile. Tests were performed using linear mixed-effects models with a river from which a crocodile was collected as a random factor (to control for multiple crocodile collections from the same locality) using package 'nlme'(Pinheiro et al. 2016) implemented in the R 3.3.0 statistical environment ( $\mathrm{R}$ Core Team 2016). The frequency distribution of dependent variables did not significantly deviate from normality after log-transformation (Kolmogorov-Smirnov tests, $\mathrm{d}=0.14-0.25$, $\mathrm{p}>0.20$ for all).

In addition, we tested whether the sex ratio of each pentastome species within an individual crocodile differed significantly from the null expectation of unity using $\chi^{2}$ tests.

Test results were considered statistically significant if they differed at the $5 \%$ level, i.e. $\mathrm{p}<0.05$.

\section{RESULTS}

Excepting a single subadult female from the Olifants River, all crocodiles harboured pentastomid parasites (total prevalence $97 \%$ ), with an overall mean abundance of 23.4 pentastomids per individual (0-81) (Table 2). A total of 749 adult pentastomes were collected and identified to species level, representing six species comprising three genera of the family Sebekidae: A. nilotici Riley et Huchzermeyer, 1995, Alofia simpsoni Riley, 1994, Leiperia cincinnalis, Sebekia cesarisi Giglioli in Sambon, 1922, S. minor (Wedl, 1861) and S. okavangoensis Riley et Huchzermeyer, 1995. Overall mean species richness was $3.1(0-6)$ and infections with more than one pentastome species were common. In fact, 65\% (20/31) of the infected hosts harboured three or more species. Single infections were found in $16 \%(5 / 31)$ of the infected crocodiles, whereas $7 \%(2 / 31)$ carried the full species complement.

Although the nasopharyngeal region of each crocodile was examined, members of the Subtriquetridae were not found. Representatives of Alofia and Sebekia were collected from the bronchioles and lung parenchyma, whereas mature adult L. cincinnalis were found in the trachea and bronchi, with infective larvae and immature adult males and females being located in the heart and pulmonary artery.

We did not find any significant effect of either explanatory variable, be it biotic (host sex and age) or abiotic (river system), on either dependent variable (Table 3). In general, 
Table 3. Summary of linear mixed-effects models of the effect of a crocodile sex, age and river system in which it was collected on the number of adult pentastomid individuals (AP) and species (SR), infective larvae of Leiperia cincinnalis (ILLC) and infective larvae of Alofia/Sebekia (ILAS). Reference levels for independent variables were female for sex, adult for age and Limpopo for river system.

\begin{tabular}{llccc}
\hline $\begin{array}{l}\text { Dependent } \\
\text { variable }\end{array}$ & Explanatory & Coefficient estimate $\pm \mathrm{SE}$ & $t$ & $p$ \\
\hline AP & Sex & $-0.10 \pm 0.22$ & -0.46 & 0.65 \\
& Age & $-0.12 \pm 0.29$ & -0.42 & 0.68 \\
& River system & $-0.14 \pm 0.25$ & -0.55 & 0.59 \\
\hline ILLC & Sex & $-0.53 \pm 0.26$ & -1.98 & 0.18 \\
& Age & $0.54 \pm 0.36$ & 1.49 & 0.27 \\
& River system & $0.04 \pm 0.40$ & 0.10 & 0.92 \\
\hline ILAS & Sex & $0.29 \pm 0.33$ & 1.63 & 0.24 \\
& Age & $0.34 \pm 0.47$ & 0.71 & 0.55 \\
& River system & $-0.02 \pm 0.35$ & -0.07 & 0.95 \\
\hline SR & Sex & $-0.03 \pm 0.07$ & -0.40 & 0.69 \\
& Age & $-0.10 \pm 0.09$ & -1.12 & 0.28 \\
& River system & $-0.06 \pm 0.09$ & -0.62 & 0.56 \\
\hline
\end{tabular}

crocodiles harboured similar numbers of adult pentastomids, infective larvae of $L$. cincinnalis and infective larvae of Alofia/Sebekia as well as pentastomid species independently of sex, age or a river system which they inhabited.

Similarly, irrespective of the biotic or abiotic factors considered, prevalence and mean abundance of overall pentastomid infection did not vary substantially within subgroups (Table 4).

On pentastomid species level, overall prevalence ranged from $34 \%$ to $72 \%$ (Table 2), and was highest in S. cesarisi, followed by $S$. minor and L. cincinnalis. Led by S. minor, these were also the three species with the highest total count and mean abundance. Infective larvae of $L$. cincinnalis and those of the remaining Sebekidae did have a similar overall prevalence (34\% and $38 \%$, respectively) and mean abundance (3.0 and 2.1, respectively).

Table 5 summarises the prevalence and mean abundance of adults of the six pentastome species as well as the two groups of infective larvae within the various population subgroups. A similar trend as for the overall adult pentastome population can be observed for adults of a given species which appear largely unaffected by biotic or abiotic factors.

No seasonal tendencies could be observed with regard to prevalence, abundance or species richness in overall pentastomid infections, nor with regard to prevalence and abundance in adults of individual pentastome species or the two groups of infective larvae.

Lastly we had a look at the distribution of male and female pentastomes within a given species. At a first glance all species except one demonstrated female bias in the sex ratio (Fig. 2), but statistically this was confirmed for L. cincinnalis $\left(\chi^{2}=29.4, \mathrm{p}<0.03\right)$ and $S$. minor $\left(\chi^{2}=52.3\right.$, $\mathrm{p}<0.001)$ only, whereas sex ratio in infrapopulations of the remaining species did not differ from unity $\left(\chi^{2}=5.9-11.1\right.$, $\mathrm{p}>0.52$ for all).
Table 4. Prevalence, species richness and means of overall pentastomid infection in Nile crocodiles in the Kruger National Park and its vicinity, South Africa.

\begin{tabular}{llcccc}
\hline Population & Subgroup & $\mathrm{N}$ & Prev (\%) & MA (range) & MSR (range) \\
\hline Sex & Males & $18 / 18$ & 100 & $26.0(1-81)$ & $3.2(1-6)$ \\
& Females & $13 / 14$ & 93 & $20.1(0-59)$ & $2.9(2-5)$ \\
\hline \multirow{2}{*}{ Age } & Adults & $25 / 25$ & 100 & $25.5(1-73)$ & $3.3(1-6)$ \\
& Subadults & $6 / 7$ & 86 & $15.9(0-81)$ & $2.5(1-5)$ \\
\hline \multirow{2}{*}{ System } & Incomati & $6 / 6$ & 100 & $28.0(8-81)$ & $3.8(2-5)$ \\
& Limpopo & $18 / 19$ & 95 & $25.0(0-73)$ & $3.2(1-6)$ \\
\hline \multirow{2}{*}{ Season } & Spring & $6 / 7$ & 86 & $24.9(0-81)$ & $2.7(1-5)$ \\
& Summer & $5 / 5$ & 100 & $9.8(1-16)$ & $2.8(1-5)$ \\
& Autumn & $2 / 2$ & 100 & $53.0(43-63)$ & $3.5(3-4)$ \\
& Winter & $18 / 18$ & 100 & $23.3(1-73)$ & $3.2(1-6)$ \\
\hline
\end{tabular}

$\mathrm{N}$ - number of infected hosts $v s$ number of hosts examined; Prev - prevalence; MA - mean abundance; MSR - mean species richness.

\section{DISCUSSION}

In the present study we investigated the influence of biotic (host age and sex) as well as abiotic factors (river system) on the pentastome assemblages of Nile crocodiles. Pentastomids were found to be widespread parasites in Nile crocodiles in the KNP and its vicinity, with a high overall prevalence and mean abundance recorded from both river systems draining the park (Table 4). These results suggest a widespread and even distribution of pentastomes in the primary source of infection to the crocodiles, i.e. fish intermediate hosts, throughout the study area. Information on which of the numerous fish species inhabiting the waters of the KNP are susceptible to pentastomid infection is scant (see below). However, two of the known intermediate hosts of pentastomids parasitising Nile crocodiles, Mozambique tilapia, Oreochromis mossambicus Peters, and redbreast tilapia, Tilapia rendalli Boulanger (Cichlidae) (Junker et al. 1998), are widely distributed within the KNP and have been recorded from all its perennial rivers, the Levuvhu, Letaba, Olifants, Sabie and Crocodile Rivers, as well as from two seasonal rivers, the Shingwedzi and Nwanedzi Rivers (Roux et al. 2008).

Infections persisted throughout the year and typically (65\% of infected hosts) comprised a minimum of three of the six species present in Crocodylus niloticus. Both Sebekia cesarisi and S. minor, and to a lesser extent Leiperia cincinnalis, were distinctly more prevalent than Alofia nilotici, A. simpsoni and S. okavangoensis, the latter two of which shared the lowest prevalence (Table 2). Similarly, mean abundance was considerably higher in $S$. minor than in all other species, followed by that of $L$. cincinnalis and $S$. cesarisi. Hence, based on prevalence and abundance, $S$. minor clearly emerges as the dominant species in the examined pentastome assemblages, followed by L. cincinnalis and S. cesarisi. Sebekia okavangoensis and both Alofia spp. were characterised by an intermediate prevalence of more than $10 \%$ but less than $50 \%$ and an overall mean abundance of 1.3 and less, and formed the rarer component of pentastome communities. The observed differences in prevalence and abundance between the various pentastome 
Table 5. Infection parameters of pentastomid species collected from Nile crocodiles in the Kruger National Park, South Africa.

\begin{tabular}{|c|c|c|c|c|c|c|c|c|c|c|c|c|c|}
\hline \multicolumn{2}{|l|}{ Species } & \multicolumn{3}{|c|}{ Leiperia cincinnalis IL } & \multicolumn{3}{|c|}{ Leiperia cincinnalis } & \multicolumn{3}{|c|}{ Alofia nilotici } & \multicolumn{3}{|c|}{ Alofia simpsoni } \\
\hline Population & Subgroup & $\mathrm{N}$ & Prev $(\%)$ & MA (range) & $\mathrm{N}$ & Prev $(\%)$ & MA (range) & $\mathrm{N}$ & Prev $(\%)$ & MA (range) & $\mathrm{N}$ & Prev $(\%)$ & MA (range) \\
\hline \multirow[t]{2}{*}{ Sex } & Males & $5 / 18$ & 28 & $1.7(0-12)$ & $11 / 18$ & 61 & $2.1(0-11)$ & $9 / 18$ & 50 & $1.5(0-12)$ & $6 / 18$ & 33 & $1.1(0-5)$ \\
\hline & Females & $6 / 14$ & 43 & $4.6(0-33)$ & $7 / 14$ & 50 & $9.4(0-39)$ & $4 / 14$ & 29 & $0.7(0-5)$ & $5 / 14$ & 36 & $1.6(0-11)$ \\
\hline \multirow[t]{2}{*}{ Age } & Adults & $9 / 25$ & 36 & $3.2(0-33)$ & $14 / 25$ & 56 & $6.0(0-39)$ & $11 / 25$ & 44 & $1.4(0-12)$ & $11 / 25$ & 44 & $1.7(0-11)$ \\
\hline & Subadults & $2 / 7$ & 29 & $2.0(0-12)$ & $4 / 7$ & 57 & $2.9(0-11)$ & $2 / 7$ & 29 & $0.4(0-2)$ & $0 / 7$ & 0 & 0.0 \\
\hline \multirow[t]{2}{*}{ System } & Incomati & $4 / 6$ & 67 & $4.7(0-12)$ & $6 / 6$ & 100 & $6.0(2-11)$ & $4 / 6$ & 67 & $1.5(0-5)$ & $1 / 6$ & 17 & $0.8(5)$ \\
\hline & Limpopo & $6 / 19$ & 32 & $3.4(0-33)$ & $10 / 19$ & 53 & $6.7(0-39)$ & $7 / 19$ & 37 & $1.3(0-12)$ & $9 / 19$ & 47 & $1.4(0-4)$ \\
\hline \multirow[t]{4}{*}{ Season } & Spring & $2 / 7$ & 29 & $3.4(0-12)$ & $3 / 7$ & 43 & $2.9(0-11)$ & $3 / 7$ & 43 & $0.7(0-2)$ & $0 / 7$ & 0 & 0.0 \\
\hline & Summer & $2 / 5$ & 40 & $1.0(0-3)$ & $2 / 5$ & 40 & $1.4(0-4)$ & $1 / 5$ & 20 & $0.2(0-1)$ & $1 / 5$ & 20 & $0.4(2)$ \\
\hline & Autumn & $0 / 2$ & 0 & 0.0 & $1 / 2$ & 50 & $0.5(0-1)$ & $2 / 2$ & 100 & $1.5(1-2)$ & $0 / 2$ & 0 & 0.0 \\
\hline & Winter & $7 / 18$ & 39 & $3.7(0-33)$ & $12 / 18$ & 67 & $7.9(0-39)$ & $7 / 18$ & 39 & $1.6(0-12)$ & $10 / 18$ & 56 & $2.2(0-11)$ \\
\hline \multicolumn{2}{|l|}{ Species } & \multicolumn{3}{|c|}{ Sebekia cesarisi } & \multicolumn{3}{|c|}{ Sebekia minor } & \multicolumn{3}{|c|}{ Sebekia okavangoensis } & \multicolumn{3}{|c|}{ Sebekidae gen. sp. IL* } \\
\hline Population & Subgroup & $\mathrm{N}$ & Prev $(\%)$ & MA (range) & $\mathrm{N}$ & Prev $(\%)$ & MA (range) & $\mathrm{N}$ & Prev $(\%)$ & MA (range) & $\mathrm{N}$ & Prev (\%) & MA (range) \\
\hline \multirow[t]{2}{*}{ Sex } & Males & $13 / 18$ & 72 & $4.2(0-22)$ & $12 / 18$ & 67 & $15.9(0-54)$ & $6 / 18$ & 33 & $1.2(0-9)$ & $6 / 18$ & 33 & $2.8(0-16)$ \\
\hline & Females & $10 / 14$ & 71 & $2.5(0-8)$ & $10 / 14$ & 71 & $5.3(0-25)$ & $5 / 14$ & 36 & $0.6(0-4)$ & $6 / 14$ & 43 & $1.1(0-10)$ \\
\hline \multirow[t]{2}{*}{ Age } & Adults & $19 / 25$ & 76 & $3.2(0-12)$ & $18 / 25$ & 72 & $12.2(0-54)$ & $10 / 25$ & 40 & $1.1(0-9)$ & $10 / 25$ & 40 & $2.0(0-11)$ \\
\hline & Subadults & $4 / 7$ & 57 & $4.4(0-22)$ & $4 / 7$ & 57 & $7.9(0-44)$ & $1 / 7$ & 14 & $0.3(2)$ & $2 / 7$ & 29 & $2.4(0-16)$ \\
\hline \multirow[t]{2}{*}{ System } & Incomati & $5 / 6$ & 83 & $5.3(0-22)$ & $4 / 6$ & 67 & $12.3(0-44)$ & $3 / 6$ & 50 & $2.0(0-9)$ & $3 / 6$ & 50 & $4.7(0-16)$ \\
\hline & Limpopo & $13 / 19$ & 68 & $3.4(0-12)$ & $14 / 19$ & 74 & $11.5(0-52)$ & $7 / 19$ & 37 & $0.7(0-4)$ & $5 / 19$ & 26 & $1.3(0-10)$ \\
\hline \multirow[t]{4}{*}{ Season } & Spring & $5 / 7$ & 71 & $6.1(0-22)$ & $6 / 7$ & 86 & $14.3(0-44)$ & $2 / 7$ & 29 & $0.9(0-4)$ & $3 / 7$ & 43 & $3.0(0-16)$ \\
\hline & Summer & $4 / 5$ & 80 & $2.2(0-7)$ & $4 / 5$ & 80 & $3.0(0-7)$ & $2 / 5$ & 40 & $2.6(0-9)$ & $3 / 5$ & 60 & $2.6(0-11)$ \\
\hline & Autumn & $2 / 2$ & 100 & $7.0(7)$ & $2 / 2$ & 100 & $44.034-54)$ & $0 / 2$ & 0 & 0.0 & $1 / 2$ & 50 & $5.0(10)$ \\
\hline & Winter & $12 / 18$ & 67 & $2.4(0-11)$ & $10 / 18$ & 56 & $8.7(0-52)$ & $7 / 18$ & 39 & $0.6(0-3)$ & $5 / 18$ & 28 & $1.2(0-10)$ \\
\hline
\end{tabular}

$\mathrm{IL}$ - infective larvae; MA - mean abundance; $\mathrm{N}$ - number of infected hosts versus number of hosts examined; Prev - prevalence; * excluding Leiperia cincinnalis.

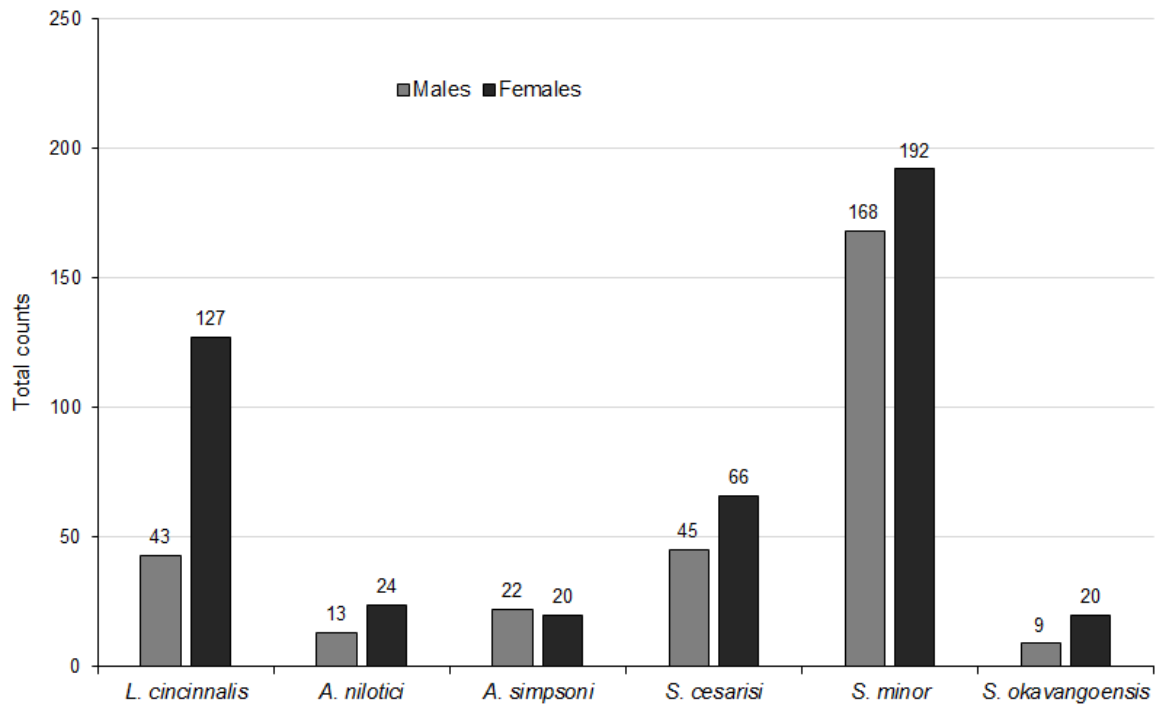

Fig. 2. Comparison of total counts of males and females within species of the pentastomid genera Leiperia Sambon, 1922, Alofia Giglioli in Sambon, 1922 and Sebekia Sambon, 1922 in Nile crocodiles in the Kruger National Park and vicinity, South Africa.

species might be related to variations in the life histories of these trophically transmitted parasites, e.g. their ability to utilise various fish species as intermediate hosts, and, in turn, the importance of these fish in the crocodiles' diet as preferential or occasional food items.

The intermediate host preference of sebekids has been found to vary. Junker (2002) recorded a higher prevalence of L. cincinnalis in O. mossambicus when compared to T. rendalli (maximum of $61 \%$ and $20 \%$, respectively, in fish $\geq 250 \mathrm{~mm}$ ) in the KNP. Conversely, sebekids other than
L. cincinnalis were more prevalent in $T$. rendalli than in O. mossambicus (maximum of $60 \%$ and $2 \%$, respectively, in fish $\geq 250 \mathrm{~mm}$ ). In addition, all sebekids showed a tendency of increasing prevalence and intensity in the larger hosts of a given fish species (Junker 2002). Information on intermediate hosts used by each of the pentastome species is scant. Sebekia minor (syn. S. wedli Giglioli in Sambon, 1922) had a prevalence of $40.5 \%$ in $T$. rendalli, but only of $2.5 \%$ in O. mossambicus in the KNP (Junker et al. 1998). An additional host reported for this pentastome in South 
Africa is the bulldog, Marcusenius macrolepidotus Peters (Mormyridae) (see Luus-Powell et al. 2008). Further intermediate host records for Sebekidae in South Africa are: L. cincinnalis from Lowveld largemouth, Serranochromis meridianus Jubb (Cichlidae), in the Incomati System; S. okavangoensis from sharptooth catfish, Clarias gariepinus Burchell (Clariidae), in the Incomati System; and Alofia sp. from O. mossambicus in the Olifants System (Junker 2002, Luus-Powell et al. 2008). Given the large diversity of fish in aquatic systems in South Africa, little is known about their capacity as hosts for pentastomid parasites.

Host age did not have a significant effect on the total number of either larval or adult pentastomes infecting crocodiles (Table 3), with a possible exception on species level, as $A$. simpsoni was not found in any of the seven subadults examined (Table 5). This is contrary to studies in the American alligator, Alligator mississippiensis (Daudin) (Alligatoridae), where prevalence and intensity of infection with $S$. mississippiensis Overstreet, Self et Vliet, 1985 was found to increase with size and its related age classes (Moreland et al. 1989, Tellez et al. 2014). Tellez et al. (2014) attributed their observations to a shift in the dietary preferences of alligators from a predominance of invertebrate prey in juveniles to mainly fish in subadults and adults, as well as to the ability of larger/older animals to capture larger intermediate fish or paratenic hosts, which can harbour heavier parasite burdens than smaller hosts.

A similar ontogenic diet shift has been demonstrated in C. niloticus (see Hutton 1987, Wallace and Leslie 2008). In Nile crocodiles from the Okavango Delta, Botswana, invertebrates made up $46 \%$ of the diet of yearlings (17.0-38.9 cm SVL) with fish only contributing $12 \%$, whereas fish constituted $68 \%$ of the diet of subadults $(66.4-115.8 \mathrm{~cm} \mathrm{SVL})$ (Wallace and Leslie 2008). In Nile crocodiles in Zimbabwe, the diet of juveniles changed from mainly insects to fish and birds at a size of $60 \mathrm{~cm}$ SVL (Hutton 1987). In the present study, the smallest crocodile, a subadult female, had reached a TL of $140 \mathrm{~cm}$, suggesting that adult as well as subadult animals had reached a size where fish form an integral part of their diet.

The lack of an effect of host age on pentastome prevalence or burden in the current study likely reflects the homogeneity of the age/size composition of the hosts examined, the resulting similarities in their diet and, consequently, exposure to infective stages of pentastomid parasites. In addition, pentastomids are long-lived arthropods, with patency reported to last as long as six years in a member of the Porocephalida (Riley 1981). Hence, infracommunities present in the crocodiles at any given moment are the accumulative result of subsequent infections over an extended period of time and not necessarily of a single infection. The observed absence of $A$. simpsoni in the seven subadult crocodiles possibly reflects the low colonisation ability of this species when compared to the more common species in the pentastome assemblages of Nile crocodiles.

Similarly, host sex had no significant effect on either larval or adult overall pentastome counts (Table 3), but it might be noteworthy that female crocodiles carried more than four times higher burdens of L. cincinnalis than males. Differences in habitat preference or prey selection between the two sexes might lead to variance in the exposure of male and female crocodiles to different intermediate hosts and/or varying numbers thereof, especially if the intermediate hosts themselves have spatially heterogeneous distributions. In American alligators, males and females were found to utilise different niches within the same habitat with a resulting difference in prey selection (Tellez et al. 2014). Although O. mossambicus (syn. T. mossambica Peters) and T. rendalli (syn. T. melanopleura swierstrae Gilchrist et Thompson), for example, have largely similar habitat preferences and both are common prey of C. niloticus (see Branch 1994), T. rendalli was recorded more frequently from perennial rivers themselves, whereas $O$. mossambicus was found to be more common in pools of seasonal rivers and dams (Pienaar 1968).

However, little is known about foraging strategies, territorial behaviour or habitat utilisation in Nile crocodiles in the KNP and much of our current knowledge on the distribution and movements of these ancient reptiles is based on studies undertaken on populations of Nile crocodiles inhabiting large lakes elsewhere in (South-) Africa (Modah 1967, Hutton 1989, Calverley and Downs 2015). Information on home range size differs somewhat with the geographic origin of crocodile populations. Home range increased with size in both male and female Nile crocodiles in the Ndumo Game Reserve, South Africa, with adult crocodiles ( $>2.5 \mathrm{~m} \mathrm{TL}$ ) occupying larger home ranges than subadults as well as using these more expansively (Calverley and Downs 2015). Contrary to this, in Kenya and Zimbabwe, large subadult females were found to travel widely throughout the available habitat without distinct home ranges, large breeding females occupied small home ranges in the vicinity of prime nest sites and large males usually had distinct home ranges (Modah 1967, Hutton 1989). If male and female Nile crocodiles in the KNP express similar behavioural differences, this might expose them to a different segment of the pentastome population. However, in this context, it is also interesting to remember that overall pentastome counts, larval or adult, were not influenced by locality, i.e. river system.

Seasonal differences have been reported in the feeding behaviour of Nile crocodiles suggesting that in subadult and adult crocodiles feeding activity is reduced during the lower temperatures prevailing in winter (Kofron 1989, Wallace and Leslie 2008). It would have been interesting to see if such altered feeding behaviour and implied changes in the exposure to infected intermediate hosts would influence pentastome abundance or whether such effects would be counterbalanced by the accumulative nature of pentastome infections. Unfortunatley, too few crocodiles were collected during the various seasons to allow meaningful interpretation of the data.

Female bias in sex ratios of polygamous endoparasites is not a scarce phenomenon (Poulin 2007), and members of the Sebekidae in the present study pose no exception. As with many of the nematodes, Riley (1972) found the sex ratio in mature infections of Reighardia sternae (Diesing, 1863) (Reighardiidae) to shift in favour of females, and 
females of the pentastomid genera Kiricephalus Sambon, 1922 (Porocephalidae) and Waddycephalus Sambon, 1922 (Sambonidae) survived longer after infection than their male counterparts (Riley and Self 1980, 1981). Poulin (1997) considered differential mortality, with higher longevity seen in females, a key factor of varying sex ratios in helminth infections.

With currently six species of pentastomid parasites recorded from it, $C$. niloticus harbours one of the most species-rich pentastomid communities among crocodilians. In fact, its pentastome diversity is only exceeded by that of the saltwater crocodile, Crocodylus porosus Schneider (Crocodylidae), from which ten nominal pentastomid species have been recorded to date (Junker and Boomker 2006, Poore 2012, Christofferson and De Assis 2013).

Interestingly, despite a considerable overlap in the distribution range of the three African crocodylid genera (Uetz and Hošek 2015), S. okavangoensis, one of the less common species in Nile crocodiles, is so far the only pentastome species shared by all. In addition, L. cincinnalis was collected from both C. niloticus and Mecistops cataphractus (see Fain 1961, Junker and Boomker 2006). Mecistops cataphractus and Osteolaemus osborni [syn. O. tetraspis and O. tetraspis osborni (Wermuth, 1953)] on the other hand, both harbour $A$. parva Riley et Huchzermeyer, 1995 and Agema silvaepalustris Riley, Hill et Huchzermeyer, 1997 (see Riley and Huchzermeyer 1995b, Riley et al. 1997, Riley and Huchzermeyer 2000), species not hitherto recorded from the Nile crocodile. It is noteworthy that Riley and Huchzermeyer (1995b) as well as Riley et al. (1997) refer to O. tetraspis obtained from Ouenze and Impfondo markets in the Republic of the Congo; in a later publication, Riley and Huchzermeyer (2000), animals from the same locality are assigned to the subspecies O. tetraspis osborni.
Members of a second family of pentastomids, the Subtriquetridae, belong to a single genus and are known to parasitise the nasopharyngeal region of crocodilian hosts (Riley 1986). To date, no adult subtriquetrids have been found in any of the African crocodiles, despite the presence of infective larvae of Subtriquetra rileyi Junker, Boomker et Booyse, 1998 in cichlids in the KNP (Junker et al. 1998). The question arises if other aquatic organisms, such as terrapins, might serve as definitive hosts for this pentastomid.

As the majority of pentastomid records from African crocodiles are based on incidental findings from single or few individuals, with only O. osborni in central Africa (Republic of the Congo) (Riley and Huchzermeyer 1995b, Riley et al. 1997) and C. niloticus in southern Africa (South Africa; the present study) having been studied in larger numbers, the apparent differences in their pentastome assemblages might as yet reflect a lack of data. Reports of unidentified pentastomid specimens, preliminarily assigned to Sebekia sp., from dwarf crocodiles in the Republic of the Congo as well as in Nigeria (Riley and Huchzermeyer 1995b, Enabulele et al. 2013), suggest that the extent of crocodilian pentastome diversity in Africa is not fully explored yet.

Acknowledgements. The authors wish to acknowledge the late Dr Fritz Huchzermeyer, South Africa, for his contribution to this crocodile survey and for bringing the parasitologists aboard. Over the years, his contribution to our knowledge on crocodiles, their diseases and parasites has been invaluable. The South African National Parks Board and the Management of the Phalaborwa Mining Complex are thanked for making the crocodiles available. Ms Chantel de Beer, ARC-Onderstepoort Veterinary Institute, kindly compiled the map indicating the collection sites. This is publication no. 914 of the Mitrani Department of Desert Ecology.

\section{REFERENCES}

Branch B. (Ed.) 1994: Field Guide to the Snakes and Other Reptiles of Southern Africa. Second Edition. Struik Publishers (Pty) Ltd., Cape Town, 326 pp.

Brochu C.A. 2007: Morphology, relationships, and biogeographical significance of an extinct horned crocodile (Crocodylia, Crocodylidae) from the Quaternary of Madagascar. Zool. J. Linn. Soc. 150: 835-863.

Bush A.O., Lafferty K.D., Lotz J.M., Shostak A.W. 1997: Parasitology meets ecology on its own terms: Margolis et al. revisited. J. Parasitol. 83: 575-583.

Calverley P.M., Downs Cт. 2015: Movement and Home Range of Nile Crocodiles in Ndumo Game Reserve, South Africa. Koedoe 57, Art. 1234, 13 pp.

Christoffersen M.L., De Assis J.E. 2013: A systematic monograph of the recent Pentastomida, with a compilation of their hosts. Naturalis Biodiversity Center. Zool. Meded., Leiden 87: $1-206$.

Crocodile Specialist Group. 1996a: Crocodylus niloticus. The IUCN red list of threatened species 1996: e. T46590A11064465. http://dx.doi.org/10.2305/IUCN.UK.1996. RLTS.T46590A11064465.en, 06/2016.

Crocodile Specialist Group. 1996b: Osteolaemus tetraspis. The IUCN red list of threatened species 1996: e. T15635A4931429. http://dx.doi.org/10.2305/IUCN.UK.1996. RLTS.T15635A4931429.en, 06/2016.
Eaton M.J., Martin A., Thorbjarnarson J., Amato G. 2009: Species-level diversification of African dwarf crocodiles (genus Osteolaemus): a geographic and phylogenetic perspective. Mol Phylogenet Evol. 50: 496-506.

Enabulele E.E., Ozemoka H.J., Awharitoma A.O., Aisien M.S. 2013: Parasitic infections of the African dwarf crocodile (Osteolaemus tetraspis) and the ornate Nile monitor (Varanus ornatus) from Nigeria. Acta Parasitol. 58: 191-197.

Fain A. 1961: Pentastomides de l'Afrique Centrale. Ann. Mus. Roy. Afr. Centr. Sér. 92: 1-115.

Hazen T.C., Aho J.M., Murphy T.M., Esch G.W., Schmidt G.D. 1978: The parasite fauna of the American alligator ( $\mathrm{Al}$ ligator mississippiensis) in South Carolina. J. Wildl. Dis. 14: 435-439.

Hutton J.M. 1987: Growth and feeding ecology of the Nile crocodile Crocodylus niloticus at Ngezi, Zimbabwe. J. Animal Ecol. 56: $25-38$.

Hutton J. 1989: Movements, home range, dispersal and the separation of size classes in Nile crocodiles. Am. Zool. 29: 1033-1049.

Junker K. 2002: A study on the Pentastomida parasitising crocodilian and chelonian final hosts, with special emphasis on the South African pentastome fauna. PhD. thesis, University of Karlsruhe, 207 pp. 
JUnker K., Boomker J. 2006: A check-list of the pentastomid parasites of crocodilians and freshwater chelonians. Onderstepoort J. Vet. Res. 73: 27-36.

Junker K., Boomker J., Bolton, L. 1999: Pentastomid infections in the Nile crocodile (Crocodylus niloticus) in the Kruger National Park, South Africa, with a description of the males of Alofia simpsoni. Onderstepoort J. Vet. Res. 66: 65-71.

Junker K., Boomker J., Booyse D.G. 1998: Pentastomid infections in cichlid fishes in the Kruger Natioanl Park, and description of the infective larva of Subtriquetra rileyi $\mathrm{n}$. sp. Onderstepoort J. Vet. Res. 65: 159-167.

Junker K., Boomker J., Swanepoel D., Taraschewski H. 2000: Leiperia cincinnalis Sambon, 1922 (Pentastomida) from Nile crocodiles Crocodylus niloticus in the Kruger National Park, South Africa, with a descriptin of the male. Syst. Parasitol. 47: $29-41$.

Kofron C.P. 1989: Nesting ecology of the Nile crocodile (Crocodylus niloticus). Afr. J. Ecol. 27: 335-341.

Kofron C.P. 1990: The reproductive cycle of the Nile crocodile (Crocodylus niloticus). J. Zool. 221: 477-488.

Luus-Powell W.J., Jooste A., Junker K. 2008: Pentastomid parasites in fish in the Olifants and Incomati river systems, South Africa. Onderstepoort J. Vet. Res. 75: 323-329.

Modha M.L. 1967: The ecology of the Nile crocodile (Crocodylus niloticus Laurenti) on Central Island, Lake Rudolf. Afr. J. Ecol. 5: 74-95.

Moreland A.F., Forrester D.J., Delaney M.F. 1989: Sebekia mississippiensis (Pentastomida) from juvenile American alligators in north central Florida. Proc. Helminthol. Soc. Wash. 56 $42-43$.

Patterson R. (Ed.) 1991: Snakes and Other Reptiles of Southern Africa. Struik Publishers, Cape Town, 128 pp.

Pienaar U.D.V. 1968: The freshwater fishes of the Kruger National Park. Koedoe 11: 1-82.

Pinheiro J., Bates D., Debroy S., Sarkar D., R Core Team. 2016: nlme: Linear and Nonlinear Mixed Effects Models. R package version 3.1-128, http://CRAN.R-project.org/package=nlme.

Poore G.C. 2012: The nomenclature of the recent Pentastomida (Crustacea), with a list of species and available names. Syst. Parasitol. 82: 211-240.

Poulin R. 1997: Population abundance and sex ratio in dioecious helminth parasites. Oecologia 111: 375-380.

Poulin R. 2007: Evolutionary Ecology of Parasites. Princeton University Press, Princeton, pp. 332.

R Core Team. 2016: R: A language and environment for statistical computing. R Foundation for Statistical Computing, Vienna, Austria. URL https://www.R-project.org/.

Riley J. 1972: Some observations on the life-cycle of Reighardia sternae Diesing 1864 (Pentastomida). Z. Parasitenkd. 40: 49-59.

RiLey J. 1981: An experimental investigation of the development of Porocephalus crotali (Pentastomida: Porocephalida) in the western diamondback rattlesnake (Crotalus atrox). Int. J. Parasitol. 11: $127-131$.

Riley J. 1986: The biology of pentastomids. Adv. Parasitol. 25: $45-128$.
Riley J. 1994: A revision of the genus Alofia Giglioli, 1922 and a description of a new monotypic genus, Selfia: two genera of pentastomid parasites (Porocephalida: Sebekidae) inhabiting the bronchioles of the marine crocodile Crocodylus porosus and other crocodilians. Syst. Parasitol. 29: 23-41.

Riley J., Hill G.F., Huchzermeyer F.W. 1997: A description of Agema, a new monotypic pentastomid genus from the lungs of the African dwarf and slender-snouted crocodiles. Syst. Parasitol. 37: 207-217.

Riley J., Huchzermeyer F.W. 1995a: Description of four species of pentastomid parasites belonging to the genera Alofia Giglioli, 1922 and Sebekia Sambon, 1922, from a single Nile crocodile Cocodylus niloticus from Botswana. Syst. Parasitol. 31: 221-238.

Riley J., Huchzermeyer F.W. 1995b: Pentastomid parasites of the family Sebekidae Fain, 1961 in West African dwarf crocodiles Osteolaemus tetraspis Cope, 1851 from the Congo, with a description of Alofia parva n. sp. Onderstepoort J. Vet. Res. 62: $151-162$.

Riley J., Huchzermeyer F.W. 2000: Diet and lung parasites of swamp forest dwarf crocodiles (Osteolaemus tetraspis osborni) in the Northern Congo Republic. Copeia 2000: 582-586.

Riley J., Self J.T. 1980: On the systematics and life-cycle of the pentastomid genus Kiricephalus Sambon, 1922 with descriptions of three new species. Syst. Parasitol. 1: 127-140.

Riley J., Self J.T. 1981: A redescription of Waddycephalus teretiusculus (Baird, 1862) Sambon, 1922 and a revision of the taxonomy of the genus Waddycephalus (Sambon, 1922), pentastomid parasites of Asian, Australian and Indonesian snakes, with descriptions of eight new species. Syst. Parasitol. 3: 243-257.

Ross C.A. (Ed.) 1989: Crocodiles and Alligators. Merehurst Press, London, $240 \mathrm{pp}$.

Roux D.J., Nel J.L., Ashton P.J., Deacon A.R., De Moor F.C., Hardwick D., Hill L., Kleynhans C.J., Maree G.A., Moolman J., Scholes R.J. 2008: Designing protected areas to conserve riverine biodiversity: lessons from a hypothetical redesign of the Kruger National Park. Biol. Conserv. 141: 100-117.

ShirLey M.H. 2014. Mecistops cataphractus. The IUCN red list of threatened species 2014: e. T5660A3044332. http://dx.doi. org/10.2305/IUCN.UK.2014-1.RLTS.T5660A3044332.en, 06/2016.

Shotts E.B., Gaines J.L., Martin L., Prestwood A.K. 1972: Aeromonas-induced deaths among fish and reptiles in an eutrophic inland lake. J. Am. Vet. Med. Assoc. 161: 603-607.

Tellez M., Haghighi A., Lavinim M. 2014: Distribution and abundance of Sebekia mississippiensis (Sebekidae) in the American alligator, Alligator mississippiensis. Comp. Parasitol. 81: 232-239.

Uetz P., Hošex J. 2015: The reptile database. Electronic database, http://www.reptile-database.org, 06/2016.

Wallace K.M., Leslie A.J. 2008: Diet of the Nile crocodile (Crocodylus niloticus) in the Okavango Delta, Botswana. J. Herpetol. 42: 361-368.

ZwEIG C.L. 2003: Body condition index analysis for the American alligator (Alligator mississippiensis). MSc thesis, University of Florida, $49 \mathrm{pp}$.

Cite this article as: Junker K., Calitz F., Govender D., Krasnov B.R., Boomker J. 2016: Pentastome assemblages of the Nile crocodile, Crocodylus niloticus Laurenti (Reptilia: Crocodylidae), in the Kruger National Park, South Africa. Folia Parasitol. 63: 040. 